\title{
Cash Management Challenges of Small Businesses in a Developing Community
}

\author{
Ms Avika Mungal \\ Lecturer, Department of Management Accounting, Faculty of Accounting and Informatics, \\ Durban University of Technology, South Africa. \\ Email: avikam@dut.ac.za
}

\section{Dr Hari Lall Garbharran}

Senior Lecturer, Department of Management Accounting, Faculty of Accounting and Informatics, Durban University of Technology, South Africa

Email: GarbharranHL@dut.ac.za

\section{Doi:10.5901/mjss.2014.v5n27p11}

Abstract

Small businesses are vital for employment and job creation in South Africa. The implementation of sound cash management practices is essential to ensure the profitability and sustainability of any successful business. The purpose of this paper is to identify the cash management challenges faced by small businesses in a developing community. This research targeted small retail businesses in the Tongaat area in KwaZulu-Natal, South Africa. The research design for this paper was descriptive, quantitative and cross-sectional. The data instrument was a questionnaire. These findings indicate a significant relationship between cash management knowledge and managing cash flow. The findings also indicate a correlation between profitability in the business and implementation of cash management practices as well as a correlation between the challenges of cash management practices and their ability to ensure profitability in their business. This paper recommends that businesses should implement cash management procedures to eliminate cash management difficulties.

Keywords: Cash management, Small businesses, Challenges, lack of knowledge, lack of implementation.

\section{Introduction and Purpose of the Study}

South Africa falls behind other third world countries with regards to promoting the development and sustainability of small businesses. Small businesses are vital for employment and job creation. The implementation of sound cash management practices is essential to ensure to profitability and sustainability of any successful business. A large number of businesses fail due to the absence of cash rather than the absence of profits. Patel (2010) indicates that cash flow management is vitally important for the business profitability, future planning and sustainability. The practice of basic concepts of cash flow management will assist businesses to plan for the unforeseen eventualities.

One possible reason for this prevalence could be that small business owners are not equipped to identify the problem areas within their businesses, due to the lack of necessary skills and tools. Likewise, many small business owners do not perform many cash management practices because they feel that they are unnecessary and time consuming.

This study investigates the challenges experienced by small retail businesses on cash management. It examines the underlying reasons why small businesses are not adequately managing their cash inflows and outflows.

The lack of support in terms of cash management knowledge and services for small businesses forms part of the motivation for the study. A further motivation for this study is that, to date, no previous research on this topic was found for the community concerned, i.e., Tongaat, in KwaZulu-Natal, South Africa.

The purpose of the study was to investigate the current cash management practices performed by the small retail businesses in the Tongaat area, in KwaZulu-Natal. Part of the study also ascertains whether certain cash management practices are being performed in small businesses and, if not, what are the challenges? Many small businesses face liquidity problems and eventually fail due to the lack of cash management knowledge and implementation. 


\section{Literature Review}

\subsection{Importance of cash management}

According to Alfred (2007), as cited by Akinyomi (2014:58), the importance of managing cash in a business comprises of the following advantages:

- Managing cash helps in achieving liquidity in a business and proper control;

- It assists in the planning towards reducing cash expenses and increasing cash receipts to ensure the business is liquid;

- Proper managed cash is vital as the future cash flow behaviour cannot be predicted. Therefore, it's essential to plan; and

- Through proper controls of cash, innovative procedures could be implemented for cash receipts and cash payments in the business.

Bobitan and Mioc (2011: 302) state that cash management embodies all incomes andpayments made within a certain period, and highlight potential inconsistencies of cash management practices.

Good cash management is necessary because too much cash is costly due to interest payments. Too little cash is also costly, because businesses will not be able to reap the advantages from economies of scale (McMahon 2006:148).

Good cash management practices are crucial for business managers. The business becomes insolvent when it fails to meet its debt timeously. Consequently, businesses need to manage their costs efficiently and effectively. Proper cash management prevents bankruptcy, thereby increasing profitability and sustainability of businesses (Mbroh 2012:40).

Proper and efficient cash management are imperative to recently established and growing small businesses. The cash flow of a small business could become problematic when the business deals with a number of customers who are difficult to track and when the business sells products which are in greater demand than its competitors.

Bobitan and Mioc (2011) emphasised the importance of cash management practices which embody all incomes and payments made within a certain period, highlighting potential inconsistencies which can appear for that period.

The language of business revolves around numbers.. The ability to understand the value of these numbers will ultimately indicate the ability to understand the business. Consequently, McMahon (2006:137) stated that "When you are out of cash, you are out of business".

\subsection{Cash management challenges of small businesses}

The following discussion relates to the cash management challenges faced by small retail businesses.

\subsubsection{Lack of cash budgeting}

Many small businesses emphasize the motto: "cash is king", but they have a very vague estimation of the amount of cash they will have in the next few months. Three quarters of businesses did not plan their expected cash inflows and cash outflows. This oversight directly affects the potential survival and sustainability of businesses. Nick (2009:3) noted that those businesses which budgeted for the future at least once a year had only a $36 \%$ chance of survival. Those that budgeted once a month for the future had increased their chance of survival to 80\%. Nick (2009:3) also highlighted that a great misconception amongst small businesses was that enhanced growth would automatically solve cash flow problems, but this growth could lead to much more cash demands if the businesses granted customer discounts solely to enhance sales.

Mong (2011:33-34), established that only $28 \%$ of the small businesses drew up cash budgets. Mong (2011:33-34) compared the cash-management techniques of 66 small businesses and found that only about $30 \%$ of the small businesses prepared cash budgets. Efficient cash management requires cash forecasting as a first step. Roughly 7 out of 10 of the small businesses surveyed did not prepare cash forecasts (Mong 2011:34).

Barry Worth, a CPA specialist, as cited by Perry (2007), indicated that many small businesses don't know what cash budgets are. Therefore, they don't practise cash forecasting to know when they will experience the peaks and valleys in their business cycles.

Amoako, Marfo, Gyau and Asamoah (2013:188-191) stated that the planning and drawing up of a cash budget can be very painful to businesses. The authors also emphasized that a cash budget could be used as a tool for imposing restrictions or even being over optimistic. 


\subsubsection{No bank accounts}

Baroncini-Moe (2013) emphasised the necessity for small businesses to have a bank account. The author indicated that many small businesses do not have a bank account. However, a bank account would facilitate the determination of profitability, enhance business professionalism and establish the legitimacy of the business. A bank account will also keep track of the cash inflows and outflows of the business.

\subsubsection{Poor cash management practices}

Kippers (2004) revealed that small business owners knew their business like nobody else. They put their heart, soul and time into making their business successful. The area in which they lacked expertise was the financial aspect of record keeping. Kippers (2004) found that businesses lacked the much needed cash management knowledge to properly control the business money. They desired to have a positive cash balance from the start of business. Unfortunately, they did not know how to go about to achieve this positive balance.

Visa Inc. (2006) indicated that 53\% of the small business owners indicated that their most challenging cash management component was receiving payments from customers. $21 \%$ noted that they had great difficulty to manage and move funds and $14 \%$ found many challenges with paying off suppliers on time. Once they indicated which component of cash management was challenging, the small business owners were also asked to identify the contributing factors of these challenges. Visa Inc. (2006) noted that slow moving cash through the business was the largest factor driving cash management challenges, especially when accurate estimates could not be made regarding the timing of cash that was owed by and cash that was owed to the business. The second most common point raised as the contributing factor was that, in order to perform cash management techniques, there was a huge amount of labourintensive administrative work which was very time consuming and difficult for owners to understand and handle along with the normal running of the business (Visa Inc. 2006).

When experiencing poor cash management, it also becomes challenging to employ and maintain skilled and knowledgeable employees (Mbroh 2012:47).

In his study, Debt (2005:8) revealed that $26 \%$ of the respondents were hesitant about applying cash management practices in the business as they claimed that it was very labour intensive work. $14 \%$ of the respondents indicated that there was a lot of administrative paper work involved with cash management practices and they simply did not have the time to do it.

\subsubsection{Cash flow difficulties}

Meng (2013) highlighted cash flow issues faced by small businesses. They revealed that the one aspect that keeps small business owners awake at night is the management of cash flows. Meng (2013) indicated that nearly $71 \%$ of businesses experience cash flow problems.

Mong (2011:33-34) believed that small business managers focused on profits rather than on cash flows. Fargo (2001:1-2) believed that cash flow difficulties are an on-going concern that one in two small businesses face. Mong (2011:33-34) also emphasised that, due to the instability of small business customer base, it would be challenging to introduce techniques used in college textbooks and practised by larger companies. Moreover, due to the lack of knowledge and resources, it will be difficult to overcome cash flow problems after they are discovered.

According to All Africa.com (2013), many business owners do not put much focus on cash flows. The biggest mistake owners make is that they confuse profits of the business with the cash flowing into the business. The aforementioned article also mentioned that, as soon as businesses are reported to have a positive cash flow balance, they make large purchases and forget about the post-dated cheques issued or the payments needed to be made at a later date. Only then do businesses realise they have insufficient funds to pay for their obligations. The article also mentioned that businesses do not plan and prioritise the payments of the expenses in order of importance and due dates.

McMahon (2013:2) indicated that one out of every three businesses fail due to poor money management. According to Josh Jones, as cited by PR Newswire (2013), many small businesses struggle with planning and accurately identifying how much cash is flowing into the business and how much cash is flowing out of the business.

Jeff Schmidt, as cited by McMahon (2013:2), revealed that the greater concern for small business owners are not about whether they are making a profit, the concern is about the business being short of much needed cash.

According to an article by The Centralian Advocate (2009:11), a misconception by businesses is that only lossmaking businesses fail and shut down. There are countless profitable businesses that have closed down due a lack of 
cash inflow to the business. The article also revealed that it doesn't necessarily mean that a business is doing well because there is an increase in revenues and a decrease in inventories. The increase in revenues is accompanied by the increase with debtors and the ability to retrieve money owed by those debtors. Having a good profit means nothing without the availability of cash to sustain the business.

Nick (2009:3) revealed that most small business owners request meetings related solely to the lack of planning. Profitability of the businesses was not a problem. When small businesses become insolvent, many say it was a matter of their own bad management decisions. Cash flow forecasting is the largest challenge that small businesses face.

From the study done by Salazar (2012:93-94) in Mexico, it was evident that small businesses were facing financial problems. He concluded that $65 \%$ of small businesses close their doors in a period of less than 24 months, while one in four survive the 24-month period with a minimal chance of growth and expansion. He also emphasised that financial difficulties and the lack of proper planning represent a central problem that affects business growth, profitability and sustainability.

\subsubsection{Obtaining a loan}

The majority of small business ventures would require some external funding at some point in the business. The very first organisations that many would approach are banks. According to Mr Valaven, the Commissioner of Industries, as cited by Business Line (2011), many small businesses are at their breaking point and risk shutting down due to the lack of funding. He also emphasised that the financing institutions have tightened up the restrictions on applications for a loan which affect the majority of the small scale units.

Christ (2009:9) indicated that financing institutions were not doing enough to assist small businesses during tough economic times. Many banks are now asking for businesses to use their private homes as collateral even though they have sufficient business assets. Consequently, businesses are sceptical to take a loan to finance the business

According to Borgia, Deanna and Shank (2003), 585 of small businesses survive for less than 5 years. Younger businesses, with a short operating history, face challenges in obtaining bank finance. A total of $64 \%$ of businesses acknowledged that they had approached three or more banks for finance. Of those businesses, $54 \%$ of businesses have being rejected for finance. Just a minor $9 \%$ have indicated that they were not turned down for bank finance.

More than $60 \%$ of the businesses that were surveyed indicated that securing a loan was challenging. Failure to secure a loan restricted their growth. The survey also revealed that $68 \%$ of the small business owners transfer their personal savings into the business (Stewart 2012:11-12).

Mbroh (2012:47) indicated that businesses also encounter difficulties in obtaining money for improvement or expansion. The irony is that it is simpler to obtain a loan when the business has money rather than when the business doesn't have the money and really needs the loan to fund the business.

Many small newly-formed businesses don't qualify for loans which impact on the availability of cash to the business. They struggle financially without the assistance from a lender. Consequently, their businesses are unable to increase the cash level to enhance and expand the business (Janklow 2009:4).

What do lenders look for? Financing institutions would like to know many details about the business before approving a loan. First and foremost, any institution will want to look at the budgets of businesses. A budget indicates a business's stability and provides some surety that it will be paid back the lender's money (McMahon 2013:140).

\subsubsection{The impact of bad debts}

A bad debt or irrecoverable debt is the product of the debtor going into insolvency or where the extra charge of tracking the debt owed is much more than the initial amount the creditor would collect (Kew and Watson 2012:173).

Bad debts can affect a business in two ways: firstly, the businesses cannot repay their accounts owing to their creditors and; secondly, the businesses' debtors, being their customers, don't pay back their accounts owing to the business. In both ways, bad debts impact negatively on the business. Many small businesses rely on income received from sales to pay off other expenses and for the operation of the business. According to Manning and Pollock (2011), the revenues that small businesses write off continue to grow because of customers who cannot pay back their accounts. Manning and Pollock (2011) indicated that, although the economy continues to grow, it would be expected that cash flows of small businesses would improve. However, the author expressed that bad debts of European and North American businesses remain high well after the recession.

Bad debts impact on the goods that were sold since no income was obtained from sales. The cost of the inventory and the settlement of other expenses need to be covered (Manning and Pollack 2011). 


\subsubsection{Inventory control challenges}

According to Marketwire (2013), 73\% of small businesses surveyed indicated that they have no inventory control system. In another survey carried out in Toronto by 575 small businesses, it was revealed that small businesses were using basic control measures to maintain inventory records. A further $32 \%$ were simply using a pen and paper system to briefly keep track of inventory or no inventory controls were in place at all.

Kinciad (2008:44) revealed that many small business owners did not implement any inventory control procedures. They indicated that they knew the figure in their head intuitively, or they knew what was moving and what was not moving in the business. Also, they didn't see the need to have controls in place.

The author also indicated that many business owners indicated that they were not aware of the necessary inventory control strategies to put in place. They simply did what they feel was right.

\subsubsection{Debtors' payments}

Debt collection is deemed to be one of the most challenging aspects for small businesses. In a survey conducted, $36 \%$ of small businesses were not able to indicate the timing of receivables (Debt 2005:8).

According to the 2010 OB10-IARP Accounts receivable survey, as indicated in, The Controllers report (2010:7-8), $41 \%$ of businesses have to increase their debtors' collection efforts. $70 \%$ of businesses indicated that they try and keep their debt collection efforts in house as they cannot afford contracting outsourced collectors. The report also revealed that $55 \%$ of businesses have to call debtors continuously in an attempt to recover their debts. $35 \%$ of those affected businesses have implemented late payment fees. Moreover, $29 \%$ of businesses indicated that they are not selling to overdue debtors anymore, until debts are paid off.

According to Charlwood (2011), 25\% of small businesses experience cash flow problems. The majority of small businesses have struggled to meet their payments because they are dealing with debtors that are not paying back their accounts. Businesses are taking longer than 90 days waiting for payments from debtors. The author also found that $30 \%$ of the affected businesses offer discounts for early payments but this incentive was an ineffective measure as debtors did not use this opportunity.

Economou (2012) also confirmed that businesses faced the same challenges regarding debtor payment. $83 \%$ of small businesses experienced very slow payment, as revealed in a small business survey. $23 \%$ of businesses write off bad debts as debtors do not repay their accounts. Just $27 \%$ of small businesses managed to get a bank overdraft to cover the gap in cash flow. The rest of the affected businesses had to use their personal finance to manage the deficit owed by debtors.

Lastly, Economou (2012) indicated that predictions for the following year seems worrying as an estimated $77 \%$ of businesses are concerned that their debtors would become insolvent and will not be able to pay back their accounts.

\subsubsection{Creditors' payments}

According to Perry (2007), many suppliers offer payment terms of 30,60 or even 90 days to consumers. Many businesses tend to repay their accounts as quickly as possible and do not use the benefit of extending terms over 30 to 90 days.

Two-thirds of small businesses in Australia are taking longer than 30 days to pay their bills. Businesses took an average of 53.4 days to pay their bills. Less than $44 \%$ of the businesses actually implement credit control procedures (Small businesses struggling so creditors have to wait longer 2011:27). This study revealed that smaller businesses with less than 5 employees suffered the worst deterioration in creditor repayment terms over the past 12 months.

\section{Research Methodology}

A descriptive study was chosen to undertake this research to discover and understand the cash management practices of the small retail businesses, which are classified as businesses with less than five employees. This was a cross-sectional study with a quantitative research paradigm.

\subsection{Sample design}

Convenience sampling was chosen for the small retail businesses in the Tongaat area comprising of a target population 
of 83 small businesses, as retrieved from the Tongaat business forum. The sample size was 69 businesses. The research was limited to the small retail businesses with not more than five employees in the Tongaat area.

\subsection{Questionnaire design}

A survey research was conducted. A questionnaire was used to measure cash management practices of small businesses. The questionnaire was designed with closed-ended Likert type questioning. The questionnaire also consisted of an open-ended question so that respondents could elaborate on business challenges which were not covered in the open-ended questions. A pilot study was undertaken to ensure that the final questionnaire was error-free and amendments were made before the data was collected for the study. The respondents were small business owners or suitable representatives of the business owners. The researcher provided a self-addressed and prepaid envelope to the respondent for the return the questionnaires.

\subsection{Data Analysis}

Statistical analysis, such as factor analysis, Cronbach's alpha, chi square test, hypotheses testing, t-test and correlations were performed on the data extracted from respondents using the SPSS version 21.0 statistical software.

\subsection{Ethics}

All the businesses in the sample were aware that all information released would remain confidential and all names would remain anonymous and would not be used for any other purpose other than this research study. No business names were mentioned in the write up of the study.

\section{Research Findings and Analysis}

The empirical findings of this study are presented below. These findings indicate the types of cash management practices and challenges faced by the small businesses in the Tongaat area.

\subsection{Cash management knowledge}

Table 1 reveals the extent of the respondents' knowledge of cash management.

Table 1: Respondents' knowledge related to cash management

\begin{tabular}{|c|c|c|}
\hline & Frequency & Percentage \\
\hline Yes & 46 & 66.7 \\
\hline No & 23 & 33.3 \\
\hline Total & 69 & 100.0 \\
\hline
\end{tabular}

Two-thirds (66.7\%) of the respondents indicated that they believe that they did have the required knowledge to manage their cash. Since $84 \%$ of the respondents were either owners or managers, it would be expected that they have some knowledge regarding cash management. A total of $33.33 \%$ indicated that they had no knowledge of cash management.

\subsection{Debtor management/sell on credit}

This section deals with the credit sales pattern of small businesses as well as how the customers pay back their overdue accounts. Figure 1 is a summary of the opinions regarding debtor management. 


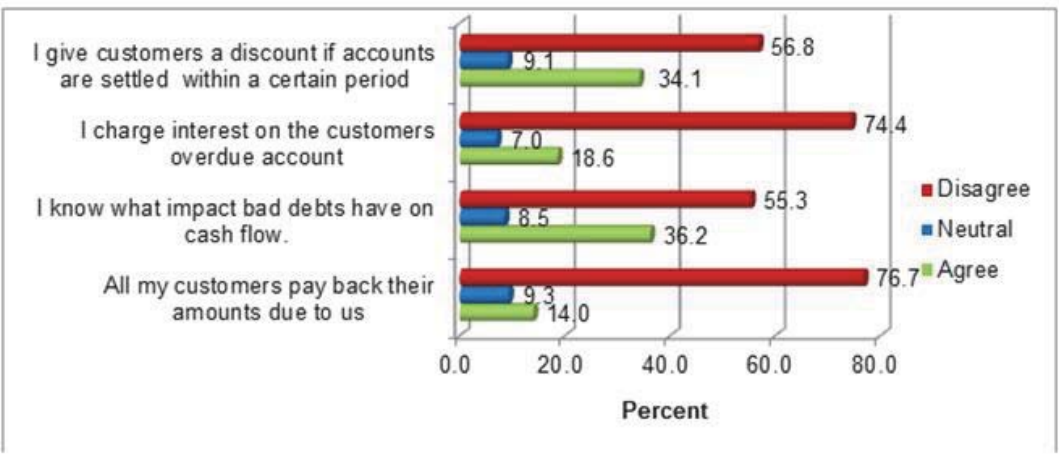

Figure 1: Debtor management

Figure 1 indicates the general trend related to levels of disagreement with each of the statements. Two statements have higher levels of disagreement (75\%), whilst the other two statements have lower levels of disagreement (56\%). $56.8 \%$ of the respondents do not encourage quick payments from customers by offering them a discount. This is the reason why customers take so long to pay back their overdue accounts. $34.1 \%$ of the respondents allow a discount to customers and 9.1\% were neutral. $74.4 \%$ of the businesses don't charge their customers an interest on the outstanding payments due. The customers, therefore, don't see the urgency in paying their accounts promptly. Many of the respondents emphasised that if they had charged interest on an overdue account, they would lose many of their regular customers. They fear that the extra charge will discourage customers to support their business. Just $18.6 \%$ of the businesses charged interest to outstanding accounts and $7 \%$ were neutral on the statement.

A staggering $76.7 \%$ of businesses acknowledge that they have customers who won't pay back their outstanding payments. However, $55.3 \%$ were not aware of how bad debt affects the cash flow of their business. This finding is in line with the high number of businesses which acknowledges that there are many customers who do not pay their accounts. According to Manning and Polack (2011), the revenues that small businesses write off continue to grow because of customers who cannot pay back their accounts. From this finding, it is evident that the trend of bad debts is continuing to increase in the European and North American small businesses. This trend is also evident in the small retail businesses in the Tongaat area. A total of $36.2 \%$ businesses understand how bad debts affect a business. $8.5 \%$ were neutral. Only $14 \%$ acknowledge that they receive payments from all their customers. $9.3 \%$ of the respondents were neutral. The poor knowledge of cash flow management is evident from the responses of these businesses.

\subsection{Inventory management}

With regards to stock, Figure 2 summarises the respondents' levels of agreement with the statements.

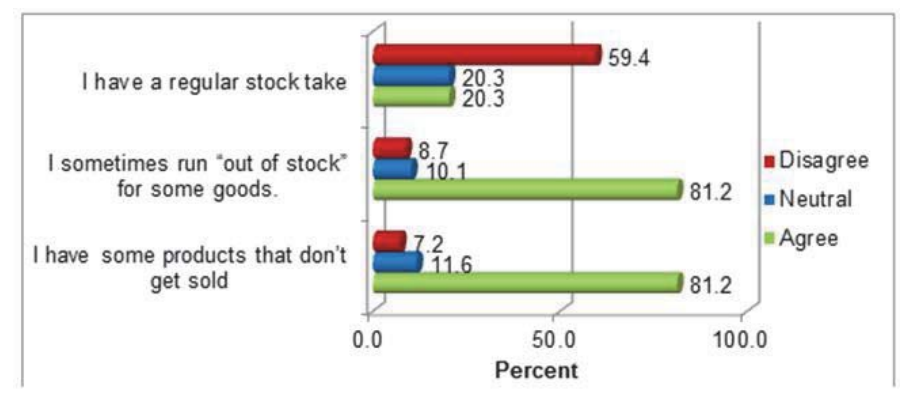

Figure 2: Respondents' opinion regarding inventory

According to Figure 2, nearly $60 \%$ of the respondents did not do a regular stock take. This finding shows that the majority of the businesses don't have proper controls and records of the inventory on the floor or shelf. $20.3 \%$ of the respondents did have a stock take and $20.3 \%$ were neutral on the statement. 
However, $81.2 \%$ indicated that some line items move more quickly than others and are sometimes out of stock, whilst a similar number of respondents indicated that certain products do not get sold easily. Consequently, if a regular stock take has been done, it could avoid the "out of stock" items. The re-order levels could be determined and more stock would be bought before the current stock is depleted. These fast selling stocks are the products which are in demand, but, by not having stock, the businesses lose customers.

$81.2 \%$ of the businesses indicate that they are stocking certain products which don't get sold. These products are lying on the shelf for a lengthy period of time resulting in the product reaching its sell-by date or the product becoming damaged and inferior to sell. Ultimately, the quality of the product becomes substandard and it is destroyed. This is an added expense to the business as proceeds for those sales could have been used for other expenses incurred. Just $8.7 \%$ of the businesses have sufficient stock and $10.1 \%$ of the respondents were neutral. $7.2 \%$ of the businesses indicated that they don't have products which sit on the shelf and that all their products do get sold. $11.6 \%$, however, were neutral.

\subsection{Control of purchases}

Figure 3 is a summary regarding control of purchases.

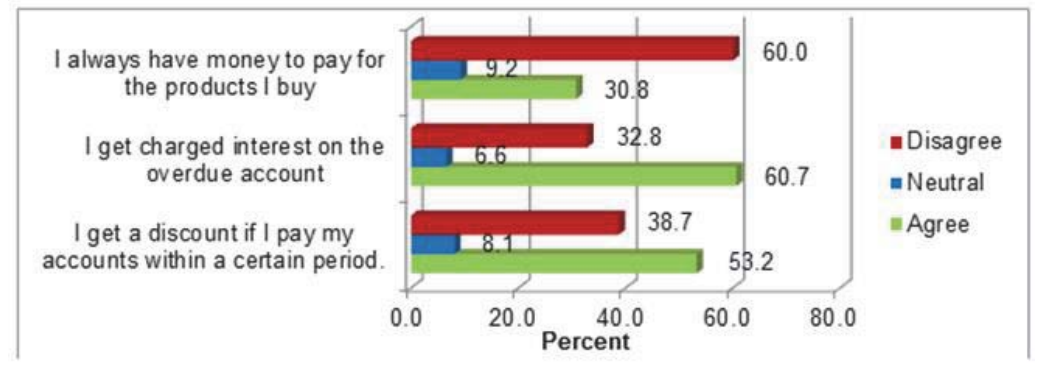

Figure 3: Control of purchases

A total of $30.8 \%$ of the respondents had sufficient reserves to pay for products purchased. $60 \%$ of these businesses purchase products without having cash available in the business. 9.2\% were neutral. This finding is in line with Inc.com (2013) which indicated that the majority of businesses incur payments before the corresponding payment is received by the business from customers. Flynn (2009:22) refers to the American Express Open Small Business Monitor's survey which targeted business owners. The results indicated that more than $60 \%$ of business owners showed concern about not having cash available to pay for their obligations.

This is the reason why only $30.8 \%$ of the businesses had cash to pay for the products purchased. $60 \%$ did not have adequate cash and $9.2 \%$ were neutral. Consequently, businesses have no choice but to purchase their products on credit. Credit purchases are accompanied by interest charges on accounts owing. Just $32.8 \%$ of the respondents indicated that they do not get charged interest on their accounts with creditors. $60.7 \%$ acknowledged that they incur this additional charge to their purchase amount.

$53.2 \%$ acknowledged that they did have an incentive of receiving a discount on their amounts owing if their accounts were settled within a specific period. $38.7 \%$ of the respondents did not receive this incentive. $8.1 \%$ were neutral. The lack of cash available to pay off accounts timeously restricts businesses from taking full advantage of this offer by their creditors.

\subsection{Finance}

Those that did have a bank account responded to the statements indicated in Figure 4. 


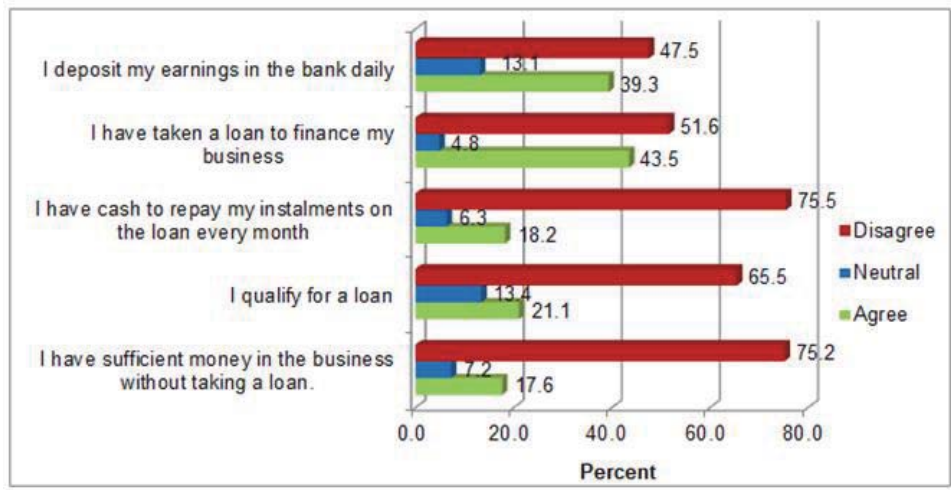

Figure 4: Bank-related statements

Figure 4 shows that there were higher levels of disagreement with each statement.

Nearly half $(47.5 \%)$ of the respondents acknowledged that they do not deposit their earnings into their bank accounts on a regular basis. By not depositing often, these businesses are keeping large amounts of cash on the business premises. Such a practice is unsafe. This is also a poor way to track cash inflow as cash keeps accumulating daily without proper records. $39.3 \%$ of businesses agreed that they deposit earnings regularly. $13.1 \%$ were neutral. $43.5 \%$ of businesses have taken a loan in order to finance their business and their operations. More than half of the businesses (51.6\%) were operating without a loan. $4.8 \%$ of the respondents were neutral.

Of those respondents who obtained a loan or borrowed money for the business, just $18.2 \%$ of them have cash available to repay their monthly instalments on the loan. $75.5 \%$ indicated that they did not have sufficient reserves available to repay the borrowed money. $6.3 \%$ were neutral.

$65.5 \%$ of the respondents wished to apply for financing by obtaining a loan but they indicated that they do not qualify for one. It is either that they have reached their credit limit or that their incomes were too low to obtain a good credit history. Just $21.1 \%$ of the respondents indicated that they did qualify for credit. $13.4 \%$ of businesses were neutral.

Janklow (2009:4) indicated that there are two reasons for business failure. Firstly, many small newly-formed businesses don't qualify for loans. Consequently, they have low cash reserves. They struggle financially without the assistance from a lender and are unable to enhance and expand the business. Secondly, businesses do not have sufficient capital to start up the business and sustain the business through any unforeseen crisis.

$75.2 \%$ of the businesses admit that there isn't sufficient money available to run their business without obtaining or having access to external funding such as a loan. Just $17.6 \%$ of the respondents agreed that they were not experiencing cash difficulties. $7.2 \%$ of the businesses were neutral.

Salazar (2012:93-94) indicated that 65\% of small businesses closed their doors in a period of less than 24 months, while one in four survive a 24-month period with a minimal chance of growth and expansion. He also emphasised that financial difficulties and the lack of proper planning affect business growth, profitability and sustainability and are the principle reasons for these businesses' demise.

\subsection{Correlation}

The correlation between "We manage our cash flow easily in the business" and "I always have money to pay for the products I buy" is .455. This finding indicates that, with proper cash management in the business, it is likely to have money to pay for purchases. Likewise, with the absence of cash management, businesses do not have the cash to develop and sustain their small business. This finding also shows that cash solves the principle issues that small businesses face. The more likely they are to have cash, the more likely businesses ensure that their records are up-todate and debts and obligations are paid.

\section{Conclusion}

The research was conducted in the context of low profitability, development and growth of small retail businesses. It seems that poor cash management is a contributing factor towards lower profitability and sustainability of small businesses. This study established that this hypothesis was prevalent and that cash management knowledge was one of 
the important elements in the success of a small business. The inquisition into the problem revealed that business managers and owners, who have basic cash management knowledge, were more profitable and had sufficient cash to handle business activities. The study also provided sufficient evidence testifying that a greater portion of owners are operating a business without formal financial records in place as well as without any higher qualification on small business management. The study confirmed that the restriction on a loan and poor debtor repayments played a role on the adverse financial performance of small businesses. The study also confirmed that, without proper cash management procedures in place, the business is less likely to be profitable and sustainable for the future. Cash management is vitally important as it is the key factor to any successful business. The commonly used expression, "Cash is king" cannot be contested as its validity is more prevalent in this research study. There should be more emphasis placed on the impact of how proper cash management can affect a small retail business. The findings of this study could be useful to potential, emerging and established owners of all types of businesses since effective and efficient cash management is an integral component of any successful business.

\section{Recommendations}

Based on the findings of this research, the following recommendations were made to address the challenges faced by small businesses.

\subsection{An implementation of basic cash management procedures}

This could be beneficial to eliminate the cash management difficulties faced by small businesses. A starting point could be to negotiate longer credit repayment periods with suppliers to prolong their payment deadline.

\subsection{Allowing discounts to debtors and implementation of stock takes}

This will encourage debtors to repay their accounts timeously and enhance the inflow of cash to the business. Likewise, charging an interest on an overdue account will also inspire debtors to pay back their accounts before they incur the extra charge. Implementing a stock take as part of business operations will assist managers in having proper control over the inventory. This will ensure that there is always stock of the products on hand and will alert managers when the stock is depleted. A stock take will also identify which products are slow sellers, so businesses can take measures to sell these products before they are obsolete or damaged.

\subsection{Financing options}

These businesses should investigate different loan options from various financing institutions. A loan will assist in the cash shortage that $75.2 \%$ of the businesses incur. This increase in cash availability could assist in the purchase of inventory and payments to creditors. By having sufficient inventory in the business, sales will be enhanced.

\subsection{Rendering cash management advice}

As part of an integrated project for the final-year, Durban University of Technology, National Diploma: Cost and Management Accounting students could be assigned tasks to provide cash management advice to these businesses. This assignment could commence with students' observations of owners' cash management practices implemented in the business. Thereafter, assistance could be rendered to businesses in managing their cash inflows and outflows. This could be done as part of community engagement for the university to engage students in industry practice. Such assistance will also benefit small businesses by enhancing their cash management knowledge to enable them to be more efficient in managing their cash and decision making which will enhance their profitability and sustainability.

\section{References}

Akinyomi, O. J. (2014). Effect of cash management on profitability of Nigerian Manufacturing firms. International journal of marketing and technology, 4(1):129-140.

All Africa.com. (2013). Small business Cash Flow Management. [Online]. Available: http://search.proquest.com/docview/135373019 (April 18, 2014). 
Amoako, K. O., Marfo, E. O., Gyau, K. E. and Asamoah. F. O.(2013). Cash Budgeting Imperative Element of Effective Financial Management. Canadian Social Science . 9(5): 188-191.

Baroncini-Moe, S. (2013). Do I Need a Business Bank Account? [Online]. Available: http://smallbusiness.chron.com/need-businessbank-account-1950.html (August 18, 2013).

Bobitan, N. and Mioc, A. D. (2011). Using information on the cash flow situation in substantiating entities' decisions. Agricultural Management [online], 13 (3): 299-306. Available at: http://search.ebscohost.com/login.aspx?direct=true\&db=bth\&AN= 67096119\&site=ehost-live (July 18, 2012).

Borgia, D., Burgess, D. O. and Shank, T. (2003). Factoring accounts receivable for small business customers. Commercial lending review 18(2):38.

Business line. (2011). Lack of funding hits small-scale units. [Online]. November 22. Available: http://search.proquest.com/docview/ 1324479169 (March 3, 2014).

Charlwood, G. (2011). Small business struggle with overdue payments. Small Business Barometer. [Online]. Available: http://search. proquest.com/docview/940833307 (April 23, 2014).

Debt. (2005). Processing cash is biggest challenge. September 20:8.

Economou, A. (2012). Slow payments sour outlook for SMEs. Business News-The Advertiser. October 9:6.

Fargo, C. (2001). Two-Thirds of Firms Suffer Cash Flow Problems, Says Small Business Study, PR Newswire. 25 May: 8.

Flynn, R. (2009). Cash flow woes BE GONE! Industrial Management, 51 (6): 20-24.

Janklow, C. (2009). Why businesses fail. Accounting today. 1 Sepember: 4.

Kew, J. and Watson, A. (2012). Financial Accounting: An introduction. (8thed.) Cape Town: Oxford Universuty Press.

Kincaid, C. (2008). Getting on track for better inventory control. Casual Living 48(10):44.

Kippers, A. (2004). Cash flow No. 1 challenge for small business owners. Telegraph Journal [online], October 19. Available: http://proquest.com/docview/423216519 (April 25, 2014).

Manning, P. and Polack, T. (2011). Winning good customers, losing bad debt [online]. Available: http://www.bain.com/publications/ articles/winning-good-customers-losing-bad-debt.aspx (November 13, 2012).

Marketwire. (2013). Why Walmart has the upper hand: Survey suggests $73 \%$ of small businesses have no inventory control systems. Archon Systems. [Online]. January 24. Available: http://search.proquest.com/docview/1272343752 (April 3, 2014).

Mbroh, J.K. (2012). Cash Management Practices of small business owners in the Cape Coast Metropolitan Area of Ghana. Asian Economic and Financial Review 2(1):40-58.

McMahon, P. (2013). Know the cash flow: Cash is critical to small business survival.

Meng, M.K. (2013). Overcoming the cash drought. The Business Times [online]. November 15. Available: http://search.proquest.com/ docview/1458563426 (April 18, 2014).

Mong, D. (2011). Follow the cash: Lessons for Capstone business courses. Journal of business \& Economics research, 9 (12): $33-44$.

Nick, S. (2009). Cashflow ignorance is big problem for firms. Domimion Post, 27 March: 3.

Patel, U. (2010). Cash Management at Indian oil Corporation Ltd. Masters in business administration, DR. D.Y. Patil University.

Perry, G. (2007). For small businesses cash flow is king [online]. Available: http://www.accountingweb.com/topic/cfo/small-businessescash-flow-king( July 12, 2013).

Salazar, A. L. (2012). The impact of financial decisions and strategy on small business competitiveness. Global Journal of business research, 6 (2): 93-94.

Small businesses struggling so creditors have to wait longer. (2011). The Gold Coast Bulletin [online]. July 28:27. Available: http://search.proquest.com/docview/879441113?accountid=10612 (May 5, 2014).

The Centralian Advocate. (2009). Cash is indeed King. [Online], September 22:11. Available: http://search.proquest.com/ docview/37611692 (April 23, 2014)

The Controllers report. (2010). IMOA [Online]. Available: www.ioma.com/fin (January 20, 2014)

VISA Inc. (2006).Commercial Perspectives: Small Business Cash Management Survey [online].United states: Visa. Available: http://usa.visa.com/download/business/resource_center/cash_management.pdf (March 2, 2012). 